\title{
Social Accountability for Adolescent Sexual and Reproductive Health
}

\section{Giri Prasad Panthi}

\begin{abstract}
Adolescent population of Nepal is facing health and social
\end{abstract} problems related to sexual, reproductive, behavioral and traditional social practices. Adolescent pregnancy, child marriage, unwanted pregnancies, Chhaupadhi (restrictions during menstruation and delivery), sexual- gender based violence, unsafe abortion, HIV/AIDS, drug addiction and suicide are major problems which have severe consequences in the lives of adolescents in Nepal. Addressing such daunting problems that adolescents are facing today needs holistic approach, going beyond health. Wider community support, civic engagement and social mobilizations are required to tackle the ASRH problems. Community Based Institutions (CBIs), Community Leaders and citizens have obligations to respond to the problems related with service delivery and ending harmful practice as a social accountability for protection, fulfill and upholding the rights of adolescents. In this context, the objective of this study is assess awareness and engagement capacity of citizens for addressing adolescent sexual and reproductive health problems as a social accountability in Baitadi District of Nepal. Descriptive and analytical research design were used to assess the level of awareness and empowerment from the citizen' perspectives. A total of 337 respondents affiliated with the five different types of community based institutions (CBIs) were interviewed using structured questionnaire for data collection and data analysis was done by using SPSS version 16.0. The preliminary results of the study reveals that majority of citizens were aware and informed about $\mathrm{SRH}$ problems of adolescents, citizens perceived that child-marriage $(15 \%)$ is the main issue of adolescents in the community followed by Gender Based Violence (13.4\%) and adolescent pregnancy (12.7\%) among others. The study reveals that citizens belonging to rural areas have more citizen, actions on preventing child marriage; awareness 
level was higher among citizens from Non-Dalit communities than in Dalit communities. Further, 59.9 percent citizens feel confident to talk about sexual-reproductive health services related concerns in the meeting whereas 32.6 percent citizens perceived that they are hesitant to speak on SRH issues. Similarly, nearly half of the citizens perceived that they were not capable of deciding freely to talk about SRH related issues in the meeting. Only 61.1 percent citizens feel confident to claim for access to quality health service as their fundamental rights from public health facilities. The study concluded that majority of citizens affiliated with Community Based Institutions were aware about characteristics and Sexual and Reproductive Health issues of adolescent population at their communities. However, still a sizeable citizen felt less confident to use their individual agency to decide freely, speaking up against existing traditional norms and shown less confident in claiming Sexual and Reproductive health service as rights. The study revealed that citizen's accountability capacity is inadequate for tackling adolescent sexual and reproductive health service provision and social behavior change at the community level and therefore this calls for the dire needs to build the capacity of vanguard citizens to contribute to improving adolescents sexual and reproductive health status.

Keywords: Adolescent Sexual and Reproductive Health, Community Based Institutions, Citizen Awareness, Citizen Empowerment, Social Accountability, Citizen Engagement, Service delivery, Social Behavior Change

\section{Introduction}

It is recognized that investing in adolescent sexual and reproductive heal this key to build human capital for future of the world. Since the International Conference on Population and Development (ICPD) in 1994, countries are attempting to address the sexual and reproductive health problems of adolescents. In 2014, there were about 1.2 billion adolescents existing in the world and 88 percent of whom living in low and middle income countries (EWEC, 2014). Globally, provision and uptake of Adolescent Sexual and Reproductive health (ASRH) service is a 
public health challenge. The large proportions of adolescents in low and middle-income countries are deprived of accessing adolescent friendly SRH services. As the United Nations and international development agencies are drafting Sustainable Development Goals (SDGs) that will follow the Millennium Development Goals in 2015 and beyond, they should address the needs of 1.2 billon adolescents for transformation of the future of humanity. According to Nepal's 2011 Census, there are 6.4 million adolescents aged 1019 and this cohort make up about $24 \%$ of the total population of Nepal (Bhandari, 2014). Adolescents are facing various sexual and reproductive health, behavioral and social problems created by traditional social norms and harmful practices such as Chhaupadi, dowry, child marriage, girls trafficking, drug abuse, gender based violence; teenage pregnancy, STI/HIV and other forms of abuse and exploitation. Addressing such daunting problems requires multi- sectoral efforts and collaboration among actors - state, civil societies, communities and families. However, so far state, CSOs, communities and families are failed to safeguard their sexual and reproductive health and rights. SRH needs of adolescent population are under served and provision of adolescent friendly services alone is not sufficient to address social behavioral problems. Access to services can be improved when health-service provisions are combined with community engagement to create a more supportive environment for promoting adolescent health seeking behaviour and increase uptake of services. Studies from around the world indicate that adolescents are often unwilling or unable to access services (WHO, 2002). Investing in health observes that 'fostering greater involvement of communities and households in promoting healthier behavior on their own part and in managing their local health services' is an integral element of the agenda for reform in the health sector (World Bank 1993, p. 170).

The notion of community engagement in health has emerged from the Alma Ata declaration on Primary Health Care in 1978 which was further emphasized by the Ottawa Charter 1986, World Bank's the world development report 1993, the Programme of Action of the International Conference on Population and Development (ICPD) in 1994, the Jakarta Declaration 1997, the Bangkok Charter 
2005, for ensuring quality of care and upholding human rights. All of these declarations highlighted the need for greater devolution of decision-making powers to communities to enable them, to take charge of their own futures and shoulder responsibility for their actions for health (Williams, 2008).

For creation of enabling supportive environment, state has to formulate sound policies, laws and establish decentralize governance structures and service delivery mechanisms for equitable delivery of services especially for poor and marginalized adolescents (Aninanya et al., 2015). Similarly, Citizens of their respective communities are also equally accountable for provision of services and creation of enabling environment for adolescent focused intervention success. Informed, empowered and engaged citizens can demand quality basic services and can hold service providers accountable for effective performances.

To achieve the targets enshrined in the ICPD and MDGs goals, responding to the needs of adolescents government of Nepal has formulated national ASRH strategy and ASRH program implementation guidelines with aim to establish 1000 adolescents' friendly health facilities by 2015 . In order to effectively operationalize the national strategies opened from above should meet the mobilization from below (Fox,2015). Active community and citizen engagement can fulfill these gaps between policies and their effective implementation at operational level. The evidences from across the globe indicate that effective citizen engagement enhance social accountability to reduces socio-cultural barriers in seeking and utilization of services and can address the performance accountability related challenges. Therefore, ASRH program design must have space for citizen engagement to address the bottlenecks impending to promote adolescent health and development (IAWG, 2007).

A number of studies have proved that informed, empowered and engaged citizens can demand quality basic services, effectively represent the voices of poor marginalized citizens, take collective actions and can hold service providers accountable for effective performances. Hence, involvement and participation of citizens, citizen groups, civil society organizations, local governments and 
service providers is must for more equitable, effective, efficient, responsive and accountable ASRH service delivery and social behavior change. Socially accountable community governance requires a balance between the capacities of both supply-side and demand-side actors to give voice to the needs and concerns of adolescents on the delivery of quality services. Demand side governance or social accountability effectiveness depends on the capacity of citizens, citizen groups and the private sectors to hold duty bearers to account (Holland et al. 2009, p. 4). Catino (1999) argued, "An informed and responsible public that demands quality sexual and reproductive health care, and holds governments and duty bearers accountable for providing it, is crucial for the effective reform of existing services(p. 27)"'.

Malena et al. (2004) define social accountability as an umbrella term for demand side governance and as a citizen-centered approach encompassing a broad range of actions that citizens, communities and civil society organizations can use to hold state mechanisms accountable. Campbell and Gogoi (2013) presented a case study of how social accountability improves maternal health, he observed three "drivers" of success in social accountability- demand for services, presence of intermediary groups which can act as lever for establishing voices of poor marginalized mothers and sensitive local leaders and services providers to the needs of needy women .

Similarly, review of empirical studies, Fox (2015) suggested that breaking poor accountability trap requires triggering virtuous circles for enabling environment and empower citizens to exercise voices "Voice needs teeth to have bite but teeth may not bite without voice". Reviewing the health related projects supported by World bank in Asia, Murthy and Klugma (2004) found that scope of community participation was limited to program management and service delivery related to family planning and safe motherhood, therefore it was further suggested to increase decentralized mechanisms, leadership effectiveness, sensitization of elected members and building capacity of citizen groups for effective demand of services. Furthermore, they suggested that service provider's skills need to be enhanced on Sexual and reproductive health services. Thus, low accountability trap or poor performance 
of health system can be addressed through citizen voices and social accountability. Furthermore, government should allocate resources to build capacity of excluded groups and CBOs, health right groups and elected representatives and providers. He further suggests that strong democracy, media and strong social movement are preconditions for community participation in sexual and reproductive health and promoting culture of human rights based approach or claiming rights.

Further more, Murthy (2008) defines accountability as performance, it refers to the processes answerable to those who make demands and enforce disciplinary actions who do not perform effectively. Likewise, Lodenstein et al., (2013) in a critical realist synthesis of literature on social accountability have presented a hypothesized framework of social accountability with a configuration of context, mechanism and outcome. They summarized that social accountability is context sensitive and outcomes are triggers by mechanisms through citizen engagement and collective action. Attre et al., (2011) recommended citizen engagement should not be limited in consultation; power delegation to citizen is must for impact on changes in their health, feeling of personal empowerment, social relationship and other social determinants of health. Only informed and empowered citizens and their agencies can effectively engage in governance process.

However, in Nepal, long political transition has been the obstruction in implementing governance at district and below level. The absences of local election in last twelve years have left the local structures without legitimately elected people's representatives (Kaini, 2013). In this political vacuum, moving from social transactional mobilization to right based citizen engagement the government of Nepal has attempted to improve governance and accountability through social mobilization at local level under Local Governance and Community Development Program (LGCDP). For right based citizen engagement requires a set of different processes and understandings from those routinely used to establish groups for service delivery, savings and credit mobilization. Under the LGCDP, Ministry of Federal Affairs and Local Development (MoFALD) of Nepal has established Ward Citizen Forums (WCF), Citizen 
Awareness Centers (CAC) in the community level. Similarly, women groups/ federations, adolescents' girls' circles and youth networks are formed and functional as community governance mechanisms. These intermediary community institutions can play vital roles by bridging between State and Citizens and can make difference in service delivery, social behavior change and development outcomes. Nevertheless, Community Based institutions and its influence in addressing the ASRH is an untapped potential in Nepal. Realizing this fact, in 2014 memorandum of understanding has been signed between Ministry for Health and Population (MOHP) and Ministry for Local Development and Federal Affairs for enhanced collaboration between local community governance and health. MOHP has introduced Local Health Governance Strengthening Program (LHGSP) as a new initiative for decentralized local health service delivery and address equity in health sector.

In this backdrop, very little studies or no studies have been conducted on Social accountability for Adolescent Sexual and Reproductive health from citizen perspectives in Nepal. It is unknown how the community governance is functioning and responding to the needs of adolescents? What is the status of their capacities, what are the practices and barriers for effective citizen engagement on service delivery and tackling social issues at grass root level? Therefore, this study aimed to assess awareness and capacity of vanguard citizens and citizen groups in the demand side governance on ASRH and bring up evidences on current situation, gaps and possible solutions for better adolescent health and behavioral outcomes. This study would contribute to fulfill the gaps in paucity of knowledge in the field of social accountability for ASRH.

\section{Methods}

Descriptive and analytical research design was used to assess the social accountability for ASRH from the citizen perspectives. The target populations for this study were 2126 Citizens affiliated with the five categories of Community Based Institutions (CBIs) namely Ward Citizen Forum (WCF), Citizen Awareness Center (CAC), Youth Network, Adolescent Girls Circle and Women Group 
from two Municipal areas (Dasarath Chand and Patan) and two Village Development Committees (Siddeshwor and Bhauneli) in Baitadi district of Far western Region of Nepal. To explore the context, quantitative data were generated through questionnaire survey applying stratified random sampling technique. Out of total number of population $(\mathrm{N}=2126)$, sample size $(\mathrm{n}=337)$ was determined by using $95 \%$ level of confidence at 0.05 acceptable margin of error.

Prior to the study, researcher obtained written permission from District Health Office and verbal consent was obtained from respondents for their volunteer participation. The validity of the instrument was maintained by thoroughly reviewing the related literature and seeking inputs of the subject experts whereas the reliability of the instrument was maintained by pre-testing the instrument on the similar setting of the study and accordingly modified the questionnaire. Socio -demographic, citizen awareness, citizen empowerment, self-efficacy related data were obtained through interview questionnaire schedule. After data collection, questionnaires were rechecked for accuracy and completeness. Data were recorded in the data entry master excel sheet and tabulated as per number of responses for each questionnaire and entered in to SPSS 16.0 version for further analysis. Descriptive statistics and inferential statistics were used for data analysis.

\section{Results}

General information of the respondents participated in the study

Table 1. Socio-demographic data of all respondents $(n=337)$

\begin{tabular}{|c|c|c|c|c|}
\hline SN & \multicolumn{2}{|c|}{ Variables } & Frequency & Percentage (\%) \\
\hline 1 & Age & $10-19$ years & 22 & 6.5 \\
\hline & & 20-24 years & 43 & 12.8 \\
\hline & & 25-40 Years & 228 & 67.7 \\
\hline & & $41-60$ years & 42 & 12.5 \\
\hline & & $60+$ years & 2 & 0.6 \\
\hline 2 & Caste/Ethnicity & Brahmin & 54 & 16.0 \\
\hline & & Chhetri & 156 & 46.3 \\
\hline & & Dalit & 123 & 36.5 \\
\hline & & Janajati & 4 & 1.2 \\
\hline
\end{tabular}




\begin{tabular}{|c|c|c|c|c|}
\hline 3 & Education level & Illiterate & 3 & 0.9 \\
\hline & & Primary (1-5 Class) & 93 & 27.6 \\
\hline & & Secondary(6-10 class) & 140 & 41.5 \\
\hline & & Higher Sec. $(+2 \&$ above $)$ & 101 & 30.0 \\
\hline \multirow[t]{5}{*}{3} & Occupation & Agriculture & 182 & 54.0 \\
\hline & & Service & 30 & 8.9 \\
\hline & & Business & 58 & 17.2 \\
\hline & & Students & 66 & 19.6 \\
\hline & & Other & 1 & 0.3 \\
\hline \multirow[t]{3}{*}{4} & Marital Status & Unmarried & 58 & 17.2 \\
\hline & & Married & 278 & 82.5 \\
\hline & & Single & 1 & 0.3 \\
\hline \multirow[t]{4}{*}{5} & Food sufficiency & 1-3 months & 71 & 21.1 \\
\hline & & 4-6 months & 85 & 25.2 \\
\hline & & 7-9 months & 78 & 23.1 \\
\hline & & More than 9 months & 103 & 30.6 \\
\hline \multirow[t]{4}{*}{6} & VDC/Municipality & Siddehshwor & 55 & 16.3 \\
\hline & & Bhanauli & 49 & 14.5 \\
\hline & & Patan Municipality & 115 & 34.1 \\
\hline & & Dashrath Chand Municipality & 118 & 35.0 \\
\hline
\end{tabular}

Source: Field Survey, 2015

Table 1 illustrates that out of 337 respondents, 46.3 percent respondents were Chhetri followed by Dalit (36.5\%) and Brahmin (16\%). Almost all respondents were literate with $41.5 \%$ secondary level educations, majority of the respondents (54\%) were belonging to agriculture occupation and $(82 \%)$ were married and majority of respondents $(67.7 \%)$ were aged between $25-40$ years.

Table 2:Citizen's representation in the study by Community Based Institutions and $\operatorname{Sex}(\mathbf{n}=337)$

\begin{tabular}{|c|c|c|c|c|c|c|c|}
\hline \multicolumn{8}{|c|}{$\%$ of Total } \\
\hline & & \multicolumn{5}{|c|}{ Affiliated community institution group } & \multirow[t]{2}{*}{ Total } \\
\hline & & WCF & CAC & YN & $\mathrm{AGC}$ & WG & \\
\hline \multirow[t]{2}{*}{ Sex } & Male & 33.2 & 11.6 & 1.2 & & & 46.0 \\
\hline & Female & 22.3 & 21.7 & 1.2 & 5.0 & 3.9 & 54.0 \\
\hline \multicolumn{2}{|c|}{ Total } & 55.5 & 33.2 & 2.4 & 5.0 & 3.9 & 100.0 \\
\hline
\end{tabular}

Note: $\mathrm{WCF}=$ Ward Citizen Forum, $\mathrm{CAC}=$ Citizen Awareness Centers, $\mathrm{YN}=$ Youth Network, $\mathrm{AGC}=$ Adolescent Girls Circle, $\mathrm{WG}=$ Women Group Source Field survey: 2015 
There are 337 citizens participating in the sample survey, of which 46 percent are males and 54 percent females. Among total, 55.5 percent citizens are affiliated to WCF (the highest in proportion) and followed by CAC (33.2\%), Adolescent Circle (5\%), Woman group (3.9\%) and Youth Network $(2.4 \%$, the smallest in proportion). The majority of respondents are male $(33.2 \%)$ in WCF whereas the majority of females $(21.7 \%)$ in CAC.

\section{Awareness level of citizens affiliated with community based institutions on adolescent, sexual and reproductive health and behaviors}

Awareness level may associate with socio-demographic features of citizens e.g., sex, caste/ethnicity, occupation, education, time devoted in institution. The context of respondent's sociodemographic characteristics may influence the awareness level of citizens regarding the sexual, reproductive health and behavior. The data analyses demonstrate this assessment with appropriate statistical tools

Table 3 Association of respondent's background and awareness on various ASRH issues

\begin{tabular}{|c|c|c|c|c|c|c|c|c|c|c|}
\hline $\begin{array}{c}\text { Awareness } \\
\text { factors } \downarrow\end{array}$ & ڤ્. & & 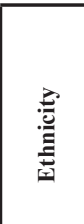 & 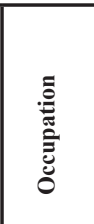 & $\frac{\Xi}{\stackrel{\Xi}{\Xi}}$ & 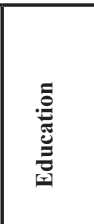 & 竞 & 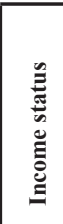 & 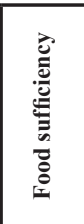 & 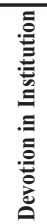 \\
\hline $\begin{array}{c}\text { Adolescent } \\
\text { age is between } \\
10-19 \text { years }\end{array}$ & $9.09 * *$ & 0.89 & $12.89^{*}$ & $22.19 * * *$ & 8.91 & $21.09 * * *$ & 11.99 ** & 3.522 & 3.37 & 1.54 \\
\hline $\begin{array}{c}\text { Adolescent } \\
\text { undergo } \\
\text { physiological } \\
\text { and } \\
\text { psychological } \\
\text { changes during } \\
\text { puberty age is } \\
\text { between 10-19 } \\
\text { years } \\
\end{array}$ & 3.42 & 1.8 & $7.21^{*}$ & 12.37 & 6.52 & $30.74 * * *$ & 1.08 & 3.67 & $12.30^{*}$ & .95 \\
\hline $\begin{array}{c}\text { Adolescents } \\
\text { SHR } \\
\text { problems } \\
\text { are different } \\
\text { from other } \\
\text { population }\end{array}$ & $5.45^{* * *}$ & 0.81 & .55 & 6.49 & 5.03 & $11.26^{* * *}$ & $11.16^{* *}$ & 2.97 & $13.27^{* *}$ & .46 \\
\hline
\end{tabular}




\begin{tabular}{|c|c|c|c|c|c|c|c|c|c|c|}
\hline $\begin{array}{c}\text { Do you } \\
\text { know about } \\
\text { the child } \\
\text { marriage? }\end{array}$ & $3.936 * *$ & 0.052 & 1.92 & 4.43 & 3.92 & $12.99^{*}$ & 2.22 & 0.01 & 1.74 & 1.31 \\
\hline $\begin{array}{c}\text { Do you know } \\
\text { there is law } \\
\text { about child- } \\
\text { marriage in } \\
\text { Nepal? }\end{array}$ & 2.43 & 0.82 & $7.58 * *$ & $16.772^{* *}$ & 6.59 & $14.35^{* *}$ & 1.83 & 7.65 & $12.23 * * *$ & .65 \\
\hline $\begin{array}{c}\text { Is any } \\
\text { incident to } \\
\text { stop child- } \\
\text { marriage? }\end{array}$ & $17.92 *$ & $3.79^{* *} \mathrm{M}$ & $3.02 * * *$ & 2.56 & $38.53 *$ & $8.45^{* *}$ & 1.84 & 4.03 & $17.73^{*}$ & $15.42^{*}$ \\
\hline $\begin{array}{c}\text { Is any report } \\
\text { registered } \\
\text { about legal } \\
\text { provision } \\
\text { of child- } \\
\text { marriage? } \\
\end{array}$ & $14.01 *$ & 9.03* & $5.12 * *$ & 5.05 & $18.87^{*}$ & 2.33 & 1.33 & 2.04 & $21.72 *$ & $6.32 * *$ \\
\hline $\begin{array}{l}\text { Do you feel this } \\
\text { ending child } \\
\text { marriage is also } \\
\text { responsibility? }\end{array}$ & 4.27 & $10.14 *$ & 1.67 & 3.35 & 6.13 & 0.95 & 0.49 & 1.59 & $13.11 * *$ & .71 \\
\hline $\begin{array}{c}\text { Is marriage } \\
\text { registration } \\
\text { practice } \\
\text { in your } \\
\text { community? }\end{array}$ & 2.72 & $18.73^{*}$ & 3.74 & $26.37^{*}$ & $63.21 *$ & 5.52 & $32.36^{*}$ & 4.64 & 9.99 & $55.43 *$ \\
\hline $\begin{array}{c}\text { Do you } \\
\text { know about } \\
\text { adolescent } \\
\text { pregnancy? }\end{array}$ & $5.92 * * \mathrm{M}$ & $11.66^{*}$ & 0.19 & $22.79 *$ & $54.25^{*}$ & 4.59 & $23.45^{*}$ & 1.0 & $11.37^{* * * *}$ & $31.42 *$ \\
\hline $\begin{array}{c}\text { Have you } \\
\text { heard about } \\
\text { GBV? }\end{array}$ & 0.49 & 0.001 & 0.96 & 4.47 & 2.89 & 26.63* & 0.76 & 2.4 & 3.46 & .74 \\
\hline \begin{tabular}{|c|} 
Are \\
adolescent \\
girls affected \\
by GBV \\
in your \\
community? \\
\end{tabular} & $7.08 * *$ & 2.9 & 0.065 & 4.39 & 7.99 & $13.19 * *$ & $11.38^{* *}$ & 2.46 & $11.76^{* * *}$ & $9.6 *$ \\
\hline \begin{tabular}{|c|} 
Are \\
adolescent \\
girls affected \\
by sexual \\
violence in \\
your c? \\
\end{tabular} & $15.82 *$ & $9.25^{*}$ & $10.33^{*}$ & 9.86 & $64.36^{*}$ & 9.44 & 5.49 & 2.08 & $47.43^{*}$ & $18.32 *$ \\
\hline
\end{tabular}

Note : $* \mathrm{P}<0.01 * * \mathrm{P}<0.05$ and $* * * \mathrm{P}<0.10$.

Note : The figure in each cell is a value of Pearson Chi-Square statistic.

Source Field survey: 2015

Table 3 presents the statistical analysis of Chi-Square test for association of two attributes with two or more levels. Here two 
attributes are 10 socio-demographic features (in columns) and 13 awareness factors (in rows) related with level of citizens' awareness on the issue of adolescent population sexual reproductive health and behavior.

\section{Awareness associated with sex of the citizens}

The column-wise relation with rows show that sex is has significant association with awareness factors related to idea of citizen on adolescent age, distinct features of adolescent problems, citizen action against child marriage, awareness on legal provision of child marriage and knowledge about adolescent pregnancy and prevalence of GBV and sexual violence in community. However, in rest of the factors sex is not significantly associated with the awareness. Significant association has been presented in the Table 3 (a) below.

Table 3 (a) Cross tabulation results of all significant association factors with sex $(N)=337$

\begin{tabular}{|c|c|c|c|}
\hline \multirow{2}{*}{ Eight Awareness Factors } & \multirow{2}{*}{ Response } & \multicolumn{2}{|c|}{ Sex } \\
\hline & & Male & Female \\
\hline \multirow{3}{*}{$\begin{array}{l}\text { Adolescent's age is between 10-19 } \\
\text { years }\end{array}$} & Yes & $85.2 \%$ & $72.0 \%$ \\
\hline & No & $3.9 \%$ & $4.9 \%$ \\
\hline & Don't Kn & $11.0 \%$ & $23.1 \%$ \\
\hline \multirow{3}{*}{$\begin{array}{l}\text { Adolescents SHR problems are different } \\
\text { than other population }\end{array}$} & Yes & $85.2 \%$ & $86.8 \%$ \\
\hline & No & $11.6 \%$ & $6.0 \%$ \\
\hline & Don't Kn & $3.2 \%$ & $7.1 \%$ \\
\hline \multirow[t]{2}{*}{ Do you know about the child-marriage } & Yes & $87.7 \%$ & $79.7 \%$ \\
\hline & No & $12.3 \%$ & $20.3 \%$ \\
\hline \multirow{2}{*}{$\begin{array}{l}\text { Is any incident in stopping of child- } \\
\text { marriage during or after in? }\end{array}$} & Yes & $59.4 \%$ & $36.3 \%$ \\
\hline & No & $40.6 \%$ & $63.7 \%$ \\
\hline \multirow{2}{*}{$\begin{array}{l}\text { Is any report registered about legal } \\
\text { provision of child-marriage? }\end{array}$} & Yes & $35.5 \%$ & $17.6 \%$ \\
\hline & No & $64.5 \%$ & $82.4 \%$ \\
\hline \multirow{3}{*}{$\begin{array}{l}\text { Do you know about adolescent } \\
\text { pregnancy and motherhood in a } \\
\text { community? }\end{array}$} & Yes & $78.7 \%$ & $80.8 \%$ \\
\hline & No & $18.7 \%$ & $12.1 \%$ \\
\hline & Don't Know & $2.6 \%$ & $7.1 \%$ \\
\hline \multirow{3}{*}{$\begin{array}{l}\text { Are adolescent girls affected by GBV in } \\
\text { your community? }\end{array}$} & Yes & $78.1 \%$ & $80.8 \%$ \\
\hline & No & $16.1 \%$ & $8.2 \%$ \\
\hline & Don't Know & $5.8 \%$ & $11.0 \%$ \\
\hline
\end{tabular}




\begin{tabular}{|l|c|c|c|}
\hline \multirow{2}{*}{$\begin{array}{l}\text { Are adolescent girls affected by sexual } \\
\text { violence in your community? }\end{array}$} & Yes & $59.4 \%$ & $41.2 \%$ \\
\cline { 2 - 4 } & No & $20.0 \%$ & $18.7 \%$ \\
\cline { 2 - 4 } & Don't Know & $20.6 \%$ & $40.1 \%$ \\
\hline Column total & & 155 & 182 \\
\hline
\end{tabular}

Note : Percentage based on Column total

Source Field survey: 2015

While assessing awareness level of both male and female citizens on adolescence and ASRH, it is found to be significantly different across each of above 8 factors at $10 \%$ level of significance. However, the level of awareness about them is different at three significant levels. Naturally, the association between two attributes at one percent level is stronger than that at ten percent level. In addition, male and female citizens may have different capacities in their awareness level about the eight factors. The following tables give more illustrations in distinguishing respondent's sex and their understanding level on 8 awareness factors.

From Table 3(a), it is seen that male citizens are slightly stronger than female citizens in having more awareness on the adolescent's age, incident in stopping of child-marriage, registration about legal provision of child-marriage and adolescent girls affected by sexual violence.

However, it is found that female citizens are slightly stronger than male citizens in having more awareness on Adolescents' SHR problems, the child-marriage, adolescent pregnancy and motherhood, and adolescent girls affected by GBV. It is also clear that both sex levels are not equally aware on all the factors regarding sexual, reproductive health and behavior. Therefore, sex is one of the most determining factors about citizen awareness on adolescent sexual reproductive health.

\section{Citizen's awareness and association with location}

Likewise, Location of the citizens may affect the awareness level. Table 3 depicts that the awareness factors, e.g., incident to stop child-marriage (marginally significant 5 percent level), report registered about legal provision of child-marriage, feeling of responsibility of the ending child marriage, knowledge of marriage 
registration practice, knowledge about adolescent pregnancy and motherhood, and adolescent girls affected by sexual violence are all significantly associated with location at most five percent level of significance. The remaining factors, e.g., Adolescent's age between 10-19 years, Adolescent undergoing physiological and psychological changes during puberty age between 10-19 years, etc (see Table 3 ) are not significantly associated with the location. In other words, they have no influence of VDC or Municipality. It is evident from Table 3 that six out of thirteen awareness factors are significantly affected by location as presented above. It is interesting to note that which parts of location are more influential on them The following Table 3 (b) shows the association between awareness area and location

Table 3 (b) Cross tabulation results of all significant associated awareness factors with location $(\mathbf{N})=337$

\begin{tabular}{|l|c|c|c|}
\hline \multirow{2}{*}{ Six Awareness Factors } & \multirow{2}{*}{ Response } & \multicolumn{2}{|c|}{ Location } \\
\cline { 2 - 4 } & & VDC & Municipality \\
\hline Is there any incident on stopping & Yes & $54.8 \%$ & $43.3 \%$ \\
\cline { 2 - 4 } child marriage & No & $45.2 \%$ & $56.7 \%$ \\
\hline Is any report registered about legal & Yes & $36.5 \%$ & $21.0 \%$ \\
\cline { 2 - 4 } provision of child marriage & No & $63.5 \%$ & $79.0 \%$ \\
\hline \multirow{2}{*}{$\begin{array}{l}\text { Do you feel that ending child marriage } \\
\text { is also responsibility of citizen }\end{array}$} & Yes & $93.3 \%$ & $99.1 \%$ \\
\cline { 2 - 4 } $\begin{array}{l}\text { Is there marriage registration practice } \\
\text { in your community }\end{array}$ & Yes & $4.8 \%$ & $0.9 \%$ \\
\cline { 2 - 4 } & No & $82.7 \%$ & $0.0 \%$ \\
\cline { 2 - 4 } & Don't Know & $11.5 \%$ & $94.8 \%$ \\
\hline \multirow{2}{*}{$\begin{array}{l}\text { Do you know about adolescent } \\
\text { pregnancy and motherhood in } \\
\text { community }\end{array}$} & Yes & $5.8 \%$ & $0.0 \%$ \\
\cline { 2 - 4 } & No & $86.5 \%$ & $76.8 \%$ \\
\hline Are adolescent girls affected by sexual \\
violence in your community & Yon't Know & $5.8 \%$ & $19.3 \%$ \\
\cline { 2 - 4 } & Nes & $7.7 \%$ & $3.9 \%$ \\
\cline { 2 - 4 } & Don't Know & $9.6 \%$ & $23.6 \%$ \\
\hline Column total & & 104 & 233 \\
\hline
\end{tabular}

Note : Percentage based on Column total

Source Field survey: 2015

In Table 3(b), citizens belonging to VDCs have more idea about incident on stopping the child-marriage than those belong to 
Municipality. But this association is not very stronger as it seen that there are VDC citizens who have no idea about this thing compared to those living in Municipality. Similarly, this association is stronger about legal provision of child marriage. The awareness attribute: feeling of responsibility about the ending child-marriage seems to have weaker association but the citizens of both place have almost equally the knowledge of this attribute. Unlike above attribute, the citizens seem to have weaker knowledge in two attributes (1) about marriage registration practice in their community and (2) adolescent girls affected by sexual violence in their community with little bit severity of less idea in Municipality. Again such event happens for the awareness attribute: knowledge about adolescent pregnancy and motherhood in a community with little bit less in VDC. Thus, location is also a key determining factor to explain the status of the knowledge about the adolescence and its features.

Citizen's awareness associated with and caste/ethnicity Caste and ethnicity divides the whole sample data into broad caste category, e.g., Dalit or Non-dalit. It is expected that the awareness level may different across above 13 adolescent attributes to some extent between Dalit and Non-dalit citizens. Table 3 presents that seven attributes (rows) are significantly associated with the ethnicity at most ten percent level of significance. So, the significant attributes are:

"Adolescent age is between 10-19 years", "Adolescent undergoes physiological and a psychological change during puberty age is between 10-19 years", "know about provision of law about child-marriage in Nepal", "cases of stopping of child-marriage", "case reported against child-marriage" and "about adolescent girls affected by sexual violence in your community". The other attributes seems similar association with any category of caste. Further details are made clear from the following Table 3 (c). 
Table 3 (c) Cross tabulation results of all significant associated awareness factors with caste/ethnicity $(\mathrm{N})=\mathbf{3 3 7}$

\begin{tabular}{|l|c|c|c|}
\hline \multirow{2}{*}{ Six Awareness Factors } & \multirow{2}{*}{ Response } & \multicolumn{2}{|c|}{ Caste/ Ethnicity } \\
\cline { 2 - 4 } & Dalit & Non-dalit \\
\hline \multirow{2}{*}{$\begin{array}{l}\text { Adolescent age is between 10- } \\
\text { years }\end{array}$} & Yes & $67.5 \%$ & $84.1 \%$ \\
\cline { 2 - 4 } & No & $7.3 \%$ & $2.8 \%$ \\
\cline { 2 - 4 } & Don't Know & $25.2 \%$ & $13.1 \%$ \\
\hline \multirow{2}{*}{$\begin{array}{l}\text { Adolescents undergo physiological } \\
\text { and psychological changes }\end{array}$} & Yes & $87.8 \%$ & $92.5 \%$ \\
\cline { 2 - 4 } & No & $1.6 \%$ & $3.7 \%$ \\
\cline { 2 - 4 } & Don't Know & $10.6 \%$ & $3.7 \%$ \\
\hline \multirow{2}{*}{$\begin{array}{l}\text { Do you know is there law about child } \\
\text { marriage in Nepal }\end{array}$} & Yes & $69.1 \%$ & $81.3 \%$ \\
\cline { 2 - 4 } & No & $30.9 \%$ & $18.2 \%$ \\
\cline { 2 - 4 } & Don't Know & $0.0 \%$ & $0.5 \%$ \\
\hline \multirow{2}{*}{ Is any incident on stop child marriage } & Yes & $40.7 \%$ & $50.5 \%$ \\
\cline { 2 - 4 } & No & $59.3 \%$ & $49.5 \%$ \\
\hline \multirow{2}{*}{$\begin{array}{l}\text { Is any report registered about legal } \\
\text { provision of child marriage }\end{array}$} & Yes & $18.7 \%$ & $29.9 \%$ \\
\hline \multirow{2}{*}{$\begin{array}{l}\text { Are adolescent girls affected by sexual } \\
\text { violence in community }\end{array}$} & No & $81.3 \%$ & $70.1 \%$ \\
\cline { 2 - 4 } & Yes & $39.8 \%$ & $55.1 \%$ \\
\cline { 2 - 4 } & No & $18.7 \%$ & $19.6 \%$ \\
\hline Column total & & 123 & 214 \\
\hline
\end{tabular}

Note 6: Percentage based on Column total

Source Field survey: 2015

From the above table, the percentage of response "YES" seems more weighted for all above attributes towards Non-dalit citizens in the study area. In contrast to this, a percentage of response "NO" more attributed to the Dalit citizens. However, the proportions for each attributes between Dalit and Non-dalit are not far apart. Nevertheless, this difference is significant as declared by Table 3 in column 3. Hence, the awareness level is higher in Non-dalit than Dalit in the study area. 
Table 3 (d) Main issues prevalence in the community related to Adolescent sexual and reproductive health-perceived by respondent citizens

\begin{tabular}{|l|c|c|}
\hline \multirow{2}{*}{$\begin{array}{c}\text { Do you think the following are the main issues } \\
\text { related to ASRH in your community? }\end{array}$} & \multicolumn{2}{|c|}{ Responses } \\
\cline { 2 - 3 } & N & Percent \\
\hline Child-marriage & 318 & $15.0 \%$ \\
\hline Adolescent pregnancy & 269 & $12.7 \%$ \\
\hline Genderbasedviolence & 285 & $13.4 \%$ \\
\hline STI and HIV & 167 & $7.9 \%$ \\
\hline Chhaupadhi & 169 & $8.0 \%$ \\
\hline Sexual violence & 154 & $7.2 \%$ \\
\hline Unsafe abortion & 164 & $7.7 \%$ \\
\hline Mental illness & 196 & $9.2 \%$ \\
\hline Suicide & 159 & $7.5 \%$ \\
\hline Drug addict & 244 & $11.5 \%$ \\
\hline Total & 2125 & $100.0 \%$ \\
\hline
\end{tabular}

a. Dichotomy group tabulated at value 1 .

Source Field survey: 2015

Table 3 (d) displays results belonging to 337 citizens responses for "Yes" in selecting above listed row-wise 10 items. There are 2125 responses seen in the table and item-wise responses are displayed in the last column calculated based on the total responses. The citizens choose child-marriage (15\%) as the main issue related to ASRH in the community. It is followed by Gender Based Violence (13.4\%), Adolescent pregnancy (12.7\%) and so forth. Next the Sexual violence has the least responses and seems not taken as a main issue compared to other issues. It is followed by issues: Suicide, Unsafe abortion, STI and HIV and so forth. Thus, the fourth awareness factor has child-marriage as the strongest main issue in the ASRH.

Table 3 (e) Descriptive analysis of respondent's knowledge about legal age of marriage

\begin{tabular}{|l|l|l|}
\hline Statistics & Forboys & Forgirls \\
\hline Mean & 21.83 & 19.51 \\
\hline Std. Deviation & 2.306 & 1.788 \\
\hline Median & 21.00 & 20.00 \\
\hline Wilcoxon Z test $=-15.341^{*}$ (based positive ranks in Wilcoxon Signed Ranks Test) \\
\hline
\end{tabular}

Note $17: * \mathrm{P}<0.01$

Source Field survey: 2015 
Table 3 (e) indicates that in the view point of citizen the average legal age of boys is 21.83 years with standard deviation of 2.31 years. It also displays that the average legal age of girls is 19.51 years with standard deviation of 1.79 years. Wilcoxon Signed Ranks Test shows that there is a significant difference in median legal age between boys and girls at 1 percent level of significance. By comparing median legal ages, it is higher for boys than and girls. It seems that the time for marriage is appropriate for both sex levels. Hence, the awareness attribute regarding question about citizen's idea about legal age of marriage seems correct in the view of sampled citizens.

Table 4 Respondent's perceived capacity in talking on SRH issues in meeting

\begin{tabular}{|l|c|c|}
\hline \multicolumn{1}{|c|}{ Feel confident in taking on SRH in the meeting } & Count & Percent \\
\hline Yes & 202 & $59.9\left(65^{*}\right)$ \\
\hline No & 110 & $32.6\left(35^{*}\right)$ \\
\hline Don't Know & 25 & 7.4 \\
\hline Total & $337(312)$ & 100 \\
\hline
\end{tabular}

Note: ${ }^{*} \mathrm{P}<0.01$ for Binomial test. The figures in parentheses are based on total of 312 while ignoring the response "Don't' know".

Source Field survey: 2015

According to the results of above table, 59.9 percent citizens responded that they feel confident in talking about sexualreproductive health issues and related concerns in the meeting. While 32.6 percent seem to have no capacity for such and the rest, 7.4 percent have no idea about such event. Here the majority of the respondents have shown capacity in talking on sexual and reproductive health issues and concerns in their group meeting. The figures here represent the behavior of individual in the sample. In order to signify such behavior, the binomial test presents the significant difference in proportions between two responses "Yes" and "No" in Table 4. Here again, 65 percent of individual citizens are showing the capacity of speaking power in the meeting while 35 percent don not have such capacity. As the majority of responses towards "Yes", it can be said that the citizen as individual agency has capacity of responding without any hesitation in the meeting 
on sexual and reproductive health. With this capacity, majority of citizens are empowered on expressing SRH issues. However, significant numbers of citizens are still not capable to speak on SRH related issues.

\section{Citizen's decision making capacity by using individual agency:} Following Table 4 (1) shows the results of the status of citizen's capacity on decision making freely while participating in the group meeting.

Table 4 (1) Perceived capacity of citizens on decision making

\begin{tabular}{|c|c|c|}
\hline $\begin{array}{c}\text { Can decide freely while participating in group } \\
\text { meeting }\end{array}$ & Count & Percent \\
\hline Yes & 169 & $50.1(53)$ \\
\hline No & 151 & $44.8(47)$ \\
\hline Don't Know & 17 & 5.0 \\
\hline Total & $337(320)$ & 100.0 \\
\hline
\end{tabular}

Note: $* \mathrm{P}<0.01$ for Binomial test. The figures in parentheses are based on total of 320 while ignoring the response "Don't' know".

Source Field survey: 2015

According the table 4 (1), 50.1 percent citizens responded for "Yes" in supporting the fact that they can freely decide while participating in the group meeting. In the meantime, 44.8 percent are showing the attitude against this fact that they cannot decide freely. Only 5 percent are showing no idea about this. When the response "Don't know" is ignored, the two proportions here are showing indistinguishable character of the citizens in the decision making process. The figures here represent the behavior of individual in the sample. In order to signify such behavior, the binomial test presents insignificant difference in proportions between two responses "Yes" and "No" in Table 4(1). It means that only half of the citizens have capacity in decision making freely. Although they have such indistinguishable behavior in decision making, it is expected that the citizens can travel to health facility without permission of their parent or guardians. The following Table 4 (2) shows the results. 
Table 4 (2) Use of Individual agency

\begin{tabular}{|l|c|c|}
\hline \multicolumn{1}{|c|}{$\begin{array}{c}\text { Can go to health facility without permission of } \\
\text { your parent/guardians }\end{array}$} & Count & Percent \\
\hline Yes & 242 & $71.8\left(76^{*}\right)$ \\
\hline No & 77 & $22.8\left(24^{*}\right)$ \\
\hline Don't Know & 18 & 5.3 \\
\hline Total & $337(319)$ & 100.0 \\
\hline
\end{tabular}

Note: $* \mathrm{P}<0.01$ for Binomial test. The figures in parentheses are based on total of 319 while ignoring the response "Don't' know".

Source Field survey: 2015

According to this table, 71.8 percent citizens have capacity to travel to health facility without permission of their parents/ guardians. But this capacity is not shown by 22.8 percent of them and 5.3 percent showing no knowledge about it. Since the majority of the citizens in support of response "Yes". The expectation seems to be fulfilled that they can travel to health facility without thinking need of permission of their guardians or parents. While performing the binomial test by ignoring the response "Don't Know", the results show the significant difference in proportions of "Yes" and "No" with 76 percent responses for "Yes". Now, it is evident that they have capacity to use their individual agency in seeking health care if they need. One of them, as expected, is family planning service in which they can use freely family planning method or contraceptives as per need. The following Table 4(3) shows the results.

Table 4 (3) Individual agency to use family planning

\begin{tabular}{|l|l|l|}
\hline \multicolumn{1}{|c|}{$\begin{array}{c}\text { Can you decide freely to use family } \\
\text { planning/ contraceptives }\end{array}$} & \multicolumn{1}{|c|}{ Count } & Percent \\
\hline Yes & 239 & $70.9\left(74^{*}\right)$ \\
\hline No & 76 & $22.6\left(24^{*}\right)$ \\
\hline Don't Know & 22 & 6.5 \\
\hline Total & $337(315)$ & 100.0 \\
\hline
\end{tabular}

Note: ${ }^{*} \mathrm{P}<0.01$ for Binomial test. The figures in parentheses are based on total of 315 while ignoring the response "Don't' know".

Source Field survey: 2015 
According to this table, 70.9 percent can decide freely to use family planning methods or contraceptive without any hesitation as depicted in Table 4(3). Still 22.6 are unable to do such activity while 6.5 percent have no idea about this. Here also, majority of the citizens in the support of using the family planning services at the center. This indicates their capacity for perceiving efficacy in the engagement in the community while talking along with two capacities in the society. To support this scenario, the binomial test is performed and presents the results that there is a significant difference in proportions between two responses "Yes" and "No". Now, this test confirms that the majority have capacity to use family planning services freely even though whether their seniors prevent them for such activity Table 4(3)). As guided by the Table 4(3), it is also expected that they can feel confident to speaking up against the norms and attitude of older generation about sexuality and reproductive health. The following Table 4(4) shows the results.

Table 4 (4) Perceived deviant behavior capacity to speak up against traditional social norms on SRH

\begin{tabular}{|l|c|c|}
\hline $\begin{array}{c}\text { Feel confident to speaking up against existing } \\
\text { social norms on SRH }\end{array}$ & Count & Percent \\
\hline Yes & 206 & $61.1\left(65^{*}\right)$ \\
\hline No & 109 & $32.3\left(35^{*}\right)$ \\
\hline Don't Know & 22 & 6.5 \\
\hline Total & $337(315)$ & 100.0 \\
\hline
\end{tabular}

Note: $* \mathrm{P}<0.01$ for Binomial test. The figures in parentheses are based on total of 315 while ignoring the response "Don't' know".

Source Field survey: 2015

According to this table, 61.1 percent citizens show their feeling that they are confident to speak up against the existing social norms and attitude of older generations about the sexuality and reproductive health. But 32.3 percent say "No" for this event or they follow the norms and respect the attitude of the older generation on that perspective. While 6.5 percent have still no knowledge about this event. Since the majority of the citizens seem against the old culture or norms about the sexuality and reproductive health, it is evident that the citizens perceived deviant behavior capacity against 
social norms or breaking the culture of silence. This evidence is further justified by the binomial test. The test shows that there is a significance difference in proportion between two responses "Yes" and "No" with higher percentage of weight on response "Yes" $(65 \%)$. Along with above describes capacities and free feeling nature in decision making process, it is also further expected that the citizens can feel confident to claim, "Access to quality health service is a fundamental right of citizens" from public health facility. The following Table 4(5) shows the results.

Table 4 (5) Perceived capacity to claim Rights

\begin{tabular}{|l|l|l|}
\hline $\begin{array}{l}\text { Do you feel confident to claiming rights demanding } \\
\text { quality SRH services }\end{array}$ & Count & Percent \\
\hline Yes & 206 & $61.1\left(68^{*}\right)$ \\
\hline No & 97 & $28.8\left(32^{*}\right)$ \\
\hline Don't Know & 34 & 10.1 \\
\hline Total & $337(303)$ & 100 \\
\hline
\end{tabular}

Note: ${ }^{*} \mathrm{P}<0.01$ for Binomial test. The figures in parentheses are based on total of 303 while ignoring the response "Don't' know".

Source Field survey: 2015

According to this table, 61.1 percent citizens feel confident to claim for access to quality health service as their fundamental rights from public health service or facility. But still 28.8 percent think that they have no feeling for claiming for a good quality of health service. Further, 10.1 percent have no idea that they have a fundamental right of getting a good health service from the public health facility. But the majority tells that they have right for health service and indicates that they perceived capacity to claim health right in their society. This scenario is further justified by the binomial test. This test confirms that there is a significant difference in proportion of "Yes" and "No" with greater percentage in "Yes" $(68 \%)$.

\section{Discussion of the Findings}

Findings from the analysis about citizen awareness level indicated that large majority of the citizens are acquainted with the characteristics of adolescence and ASRH issues. However, there 
are some differences between socio-demographic characteristics of citizens. The study reveals that male citizens are slightly stronger than female citizens in having awareness on the adolescent's age, child-marriage prevention and legal provision of child-marriage in their respective communities where as it is found that female citizens are slightly stronger than male citizens in having awareness on child-marriage, adolescent pregnancy and GBV. It is also clear that both sex levels are not equally aware on all the factors regarding sexual, reproductive health and behavior. Hence, sex is one of the most determining factors for awareness about the adolescent sexual reproductive health and its features.

The study reveals that citizens belonging to rural areas or VDCs have more informed about citizen actions on prevention of childmarriage than those belong to Municipalities. This means social capital,social sense of responsibility and collective actions are stronger in rural areas than in municipal areas. However, the study shows that knowledge about adolescent pregnancy is little bit less in VDCs compared to municipalities. The citizens of both VDCs and Municipalities seem to have weaker knowledge in two attributes (1) about marriage registration practice in their community and (2) knowledge on prevalence of sexual violence in their community. Thus, location is also a key determining factor to explore the status of citizen's awareness about Adolescent Sexual and Reproductive Health.

Regarding association of awareness with respect tocaste, the study revealed that the awareness level is higher in Non-Dalit communities than in Dalit communities in the study area.

As per the weighted given by the respondents on common issues prevailing in communities regarding ASRH, the highest frequency of respondents citizen perceived that child-marriage is the main issue related to ASRH in the community. It is followed by Gender Based Violence, Adolescent pregnancy and among others. Next, the Sexual violence has the least responses and seems not to have taken as a main issue compared to other issues. Thus, child-marriage is the strongest main ASRH issue in the community. The awareness attributes regarding questions about citizen's idea about legal age of marriage seems correct in the view of almost all of the respondents. 
The study reveals that majority of the respondents feel confident in talking about sexual-reproductive health related concerns in the meeting. However, still one third respondent citizens perceived lack of capacity to talk or discuss on SRH issues in the group meeting. The study indicates that the cultural sensitivity on sexuality and reproductive matters is still strongly present in the communities.

Although large majorities of the respondents are aware about ASRH, only half of the respondents are capable to freely decide in the meeting. It is found that only half of the citizens responded for "Yes" in a query of whether they can freely decide while participating in the group meeting. In the meantime, significant respondent are showing the attitude against this fact that they cannot decide freely in meeting. Similarly, the study unpacked that nearly two third respondents felt empower to use their individual agency to decide on using family planning methods or contraceptive. This can be explained by the fact that more than one third respondents still lack self-efficacy and individual agency for making decision freely and taking self-decision for Family planning use.

Furthermore, the study shows that every three in out of five citizens perceived that they can speak up against the existing conservative norms and attitude of older generations about the sexual and reproductive health. Similarly, equal size of respondents expressed they can claim their SRH quality services as rights/ entitlement. However, more than one third of the respondents from the community based institutions as the leaders and having obligations for addressing ASRH issue expressed no confident on speaking against conservative norms on sexuality and reproduction and claiming SRH quality services is the rights.

\section{Conclusion}

The study concluded that majority of citizens affiliated with community based institutions are aware about characteristics of adolescents and problems facing by adolescent population in their communities. There is statistical significance relationship with citizen's awareness and socio-demographic background of respondents especially between sex, location and caste. While assessing some empowerment indicators on citizen's behavior in 
group with as the prerequisites for citizen voice and collective actions for addressing ASRH service delivery and social behavior change related issues of adolescent population; still a sizable respondent citizens perceived them less confident to use their individual agency in raising voices/concerns on sexual and reproductive health issues, speaking against conservative norms on SRH, making decision freely and claiming SRH as rights. The findings of the study indicated that the empowerment status of vanguard citizens who are affiliated with the community based institutions with the mandate and obligations for ASRH as part of their social accountability is still inadequate for tackling adolescent sexual and reproductive health problems through citizen engagement at the community level.

\section{Acknowledgement}

I would like to extend my gratitude to my supervisor Professor Dr. Ganesh Man Gurung for his continuous support and guidance. I would like to thank Ganesh Shahi and Kamala Pati Pant for their assistance during field work. I acknowledge constant support and guidance by Dr. Megh Raj Dangal, Dr. Rojnath Pande as the reviewers of this article. I am also thankful to the respondents of my study.

\section{References}

Aninanya, G. A., Debpuur, C. Y., Awine, T., Williams, J. E., Hodgson, A., \& Howard, N. (2015). Effects of an adolescent sexual and reproductive health intervention on health service usage by young people in Northern Ghana: A community-randomised trial. PLoS One, 10(4), e0125267. http://doi.org/10.1371/journal. pone. 0125267 .

Attree, P., French, B.,Milton, B., Povall, S., Whitehead, M., \& Popay, J. (2011). The experience of community engagement for individuals: A rapid review of evidence. Health and Social Care, 19(3), 250-260.

Bhandari, S. D. (2014). Awareness on consequences of teenage pregnancy among adolescent at Ampipal VDC, Gorkha. Journal of Advanced Academic Research, 1(1), 10-17. 
Campbell, C., Papp, S., \& Gogoi, A. (2013). Improving maternal health through social accountability: a case study from Orissa, India. Global Public Health, 8(4), 449-464. doi: 10.1080/17441692.2012.748085.

Catino, J. (1999). Meeting the Cairo challenge: progress in sexual and reproductive health: Implementing the ICPD Programme of Action. New York: Family Care International.

Elliott, E. \& Williams, G. (2008). Developing public sociology through health impact assessment. Sociology of Health \& Illness, 30(7), 1101-1116.

Every Women Every Child (2014). Updating the global strategy for women's and children's and adolescent health for the post -2015 agenda, (Paper for the work stream on Adolescent Health). EWEC

Fox, J. (2015). Social accountability: What does the evidence really say?. World Development, 72., 346-361.

Holland, J., Allyson, T., Emmanuel, T., \& Lucy, E. (2009). Measuring change and results in voice and accountability work (Working Paper 34). London: Department for International Development.

Inter-Agency Working Group (2007). On the role of community involvement in ASRH, community pathways to improved adolescent sexual and reproductive health: a conceptual framework and suggested outcome indicators. Washington DC and New York: IAWG.

Lodenstein, E., Dieleman, M., Gerretsen, B., \& Broerse, J. (2013). A realist synthesis of the effect of social accountability interventions on health service providers' and policymakers' responsiveness. Systematic Reviews, 2(1), 98-98. doi: 10.1186/2046-4053-298.

Malena, C., Forster, R.\& Singh, J. (2004). Social accountability: an introduction to the concept and emerging practice. (Social development papers no. 76). Washington, DC: World Bank. http://documents. worldbank. 
org/curated/en/327691468779445304/Socialaccountability-an-introduction-to-the-conceptand-emerging-practice.

Murthy, R. K. (2008). Strengthening accountability to citizens on gender and health. Global Public Health,3(Suppl 1), 104-120.

Murthy, R. K. \& Klugman, B. (2004). Service accountability and community participation in the context of health sector reforms in Asia: implications for sexual and reproductive health services. Health Policy Planning, 19(Supp1 1), i78-i86.

Panthi, G. P. (2014). National Adolescent sexual and reproductive health program in Nepal. Nepalese Research Journal of PHD Doctors and scholars, 1(1).

World Health Organization. (2002). Adolescent friendly health services: An impact model to evaluate their effectiveness and cost. Geneva: World Health Organization.

World Bank (1993). World Development Report 1993: Investing in health. New York: Oxford University Press for the World Bank. 